\title{
Water quality assessment of sacred glacial Lake Satopanth of Garhwal Himalaya, India
}

\author{
Ramesh C. Sharma ${ }^{1} \cdot$ Rahul Kumar $^{1}$ (])
}

Received: 28 June 2017/ Accepted: 30 October 2017/Published online: 7 November 2017

(c) The Author(s) 2017. This article is an open access publication

\begin{abstract}
Satopanth Lake is a glacial lake, located at an altitude of $4600 \mathrm{~m}$ above sea level in Garhwal Himalaya of Uttarakhand state in India where an attempt was made to assess the water quality. A total of sixteen physico-chemical parameters including temperature, hardness, alkalinity, dissolved oxygen, conductivity, $\mathrm{pH}$, calcium, magnesium, chlorides, nitrates, sulphates and phosphates were recorded during 2014 and 2015 between June and August in ice-free period. The mean values of $\mathrm{pH}$ ranged from 6.85 to 7.10 ; water temperature fluctuated from 0.1 to $0.3{ }^{\circ} \mathrm{C}$; dissolved oxygen varied from 5.90 to $6.0 \mathrm{mg} . \mathrm{L}^{-1}$; free $\mathrm{CO}_{2}$ varied from 8.40 to $8.60 \mathrm{mg} . \mathrm{L}^{-1}$; total dissolved solids varied from 88.0 to 89.5 mg. $\mathrm{L}^{-1}$; calcium from 7.88 to $7.95 \mathrm{mg} . \mathrm{L}^{-1}$; magnesium from 0.53 to $0.66 \mathrm{mg} \cdot \mathrm{L}^{-1}$. All the physico-chemical values were within the prescribed WHO/BIS limit for drinking water. Water Quality Index (WQI) calculated based on these parameters also revealed the excellent quality of lake water.
\end{abstract}

Keywords Water quality · Satopanth Lake - Garhwal Himalaya $\cdot$ Uttarakhand $\cdot$ India

\section{Introduction}

On the planet Earth, mountains cover approximately onequarter land surface, which provides home for about $12 \%$ of the global human population. According to the United

Rahul Kumar

rahul.khadwalia@gmail.com

1 Department of Environmental Sciences, H.N.B. Garhwal University (A Central University), Srinagar-Garhwal, Uttarakhand 246174, India
Nations Conference on Sustainable Development (UNCSD 2012) which was held in Rio de Janeiro, Brazil, "mountain ecosystems play a crucial role in providing water resources to a large portion of the world's population". Lakes are vigorous inland aquatic systems of variable size, filled with water, localized in a basin, and surrounded by land. All lakes originating by present or past glaciers, in both continental ice sheets and mountain glaciers, are described as glacier lakes or glacier-fed lakes (Fairbridge 1968). The lakes present above $3500 \mathrm{~m}$ altitude are considered to be evolved due to retreat of glaciers and are classified as glacial lakes (WWF 2005). These lakes are a good and precious source of clean and fresh water. Most of these lakes are small and shallow in size, but they tend to connect to each other and grow into a large conterminous lake within the glacier ice. The Garhwal Himalaya has several glacier-fed lakes or glacial lakes above an altitude of more than 3,500 $\mathrm{m}$ above m.s.l. These glacier-fed lakes are the main source of drinking water for sages, trekkers, wild animals and local inhabitants. The Satopanth Lake is one of the most important and biggest sacred glacier-fed lakes of the Garhwal Himalaya.

Though some works have been done on different aspects of glacial lakes, such as the works of Ageta et al. (2000) on glacier lakes of Bhutan, Fujita et al. (2012) on glacier lakes outburst flood in Bhutan, Raj et al. (2013) on glacial lakes of Sikkim, Mihaiescu et al. (2013) on glacial lakes of Romania, Pu et al. (2013) on glacial lake Ximencuo, Che et al. (2014) on glacial lakes of Tibbet, Westoby et al. (2014) on modeling of outburst floods from moraine dammed glacial lakes and Bhambri et al. (2015) on Inventory of glacier lakes of Uttarakhand. But, no work has been done so far on the water quality of any glacier-fed lake of Garhwal Himalaya. Therefore, to provide basic data on the water quality of Satopanth, a glacier-fed lake of the 
Garhwal Himalaya was used for reference for further studies.

\section{Study area}

Satopanth Lake is one of the important and biggest glacial lake of Alkapuri glacier of the Garhwal Himalaya in the state of Uttarakhand, India (Fig. 1). It is located in the midst of snow-capped peaks at an altitude of $4600 \mathrm{~m}$ above mean sea level (latitude $30^{\circ} 44^{\prime} 682^{\prime \prime} \mathrm{N}$ and longitude $\left.79^{0} 21^{\prime} 468^{\prime \prime} \mathrm{E}\right)$. No documented information is available on the Satopanth Lake, except the location and type of this lake (lateral moraine dammed lake), with the help of satellite images during 2011-2013 by Bhambri et al. (2015). This lake has religious significance to local people and it is considered sacred for them. Residents of Mana village, the last border village of India, immerse the ashes of their dead ones in this lake. Satopanth Lake is $25 \mathrm{~km}$ away from Badrinath, the world famous temple of Hindus. Kuber top, Mt. Nilkantha and Mt. Swargarohini are the important peaks visible enroute to the lake. The lake remains under snow from the end of September to the end of May or sometimes up to the end of June. The normal

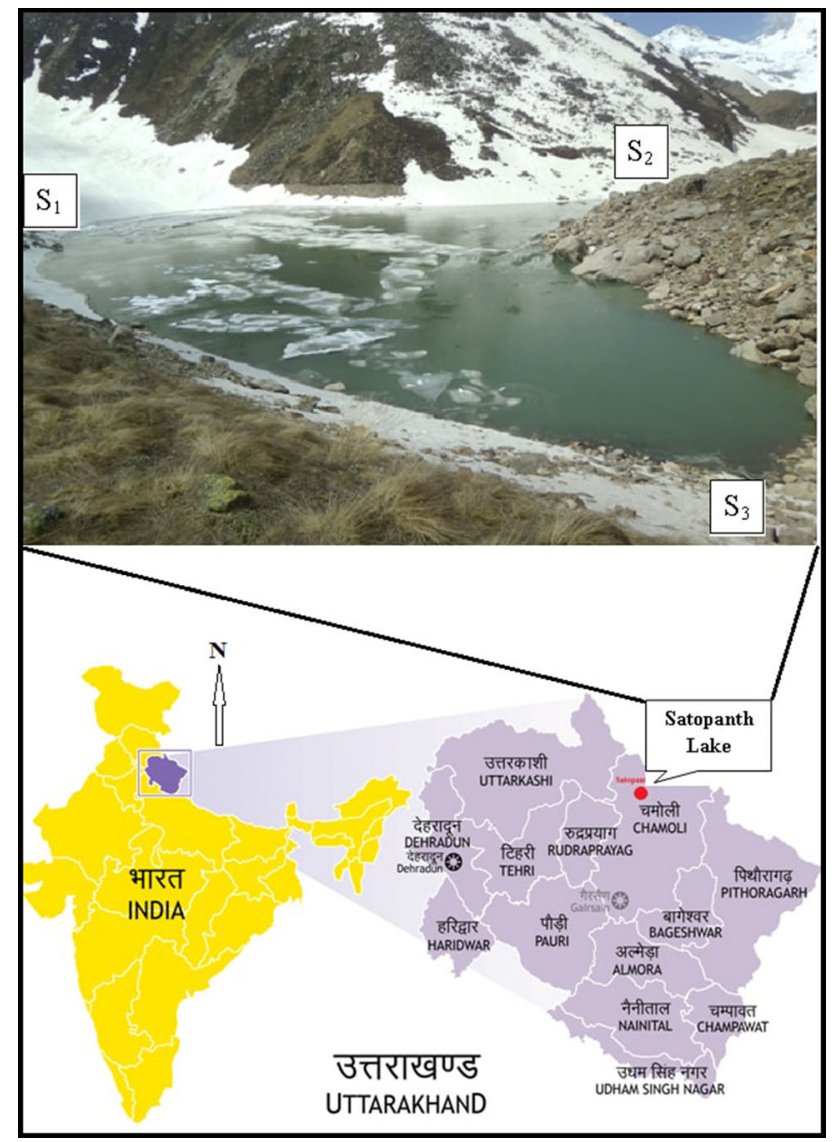

Fig. 1 The study area summer temperature remains around 10 to $12{ }^{\circ} \mathrm{C}$ during day time and 5 to $-5{ }^{\circ} \mathrm{C}$ during night, while winter temperature may drop to -20 to $-25{ }^{\circ} \mathrm{C}$ during day and -30 to $-35^{\circ} \mathrm{C}$ during night hours.

Satopanth Lake with its emerald blue-green crystal clear water is triangular in shape with three corners spread within the circumference of more than one $\mathrm{km}$. This pristine lake is situated at the base of Mt. Nilkantha peak. The approximate area of the lake is $2553 \mathrm{~m}^{2}$ with the length of about $358 \mathrm{~m}$ and depth is approximately $15-20 \mathrm{~m}$. Geologically, this is a glacial corrie lake or tarn which is dammed by moraines. The Alkapuri glacier is a huge glacier and a lot of tarns are formed close to this glacier. The water of the lake is held by the vast boulders and lateral moraines of the glacier.

No vegetation is found except few herbs during summers at and near the Satopanth Lake. However, two plant species (Betula utilis and Juniperus sp.) are dominantly found near Laxmivan and Chakratirth enroute to Satopanth Lake. Betula utilis, commonly known as "Bhojpatra" is a birch tree native to the Himalaya, growing at elevation up to $4500 \mathrm{~m}$. Juniperus species is a coniferous plant of the Cupressaceae family. It is widely used in India by the Hindus for worshiping the God.

\section{Materials and methods}

\section{Water sampling}

The lake water was sampled during 2014 and 2015 in two sampling operations each year. In both the years, sampling made in the months of June and August, the ice-free periods, as the lake is accessible only for a limited span of time. Water samples were collected from three different sites $\left(S_{1}, S_{2}\right.$ and $\left.S_{3}\right)$ of the lake at about $30 \mathrm{~cm}$ below the surface water using autoclaved thermoflask in the morning time between 9:00 to 11:00 h. Water quality parameters, such as $\mathrm{pH}$, air temperature, water temperature and dissolved oxygen, were measured at the sampling site. For the remaining parameters, the water samples were transferred to the Laboratory of Environmental Microbiology, Department of Environmental Sciences, H.N.B. Garhwal University (A Central University), Srinagar-Garhwal, Uttarakhand, India. All the physico-chemical parameters and coliform test were analyzed by following the standard methods outlined in Wetzel and Likens (1991); APHA (1998).

\section{Coliform detection}

For water quality analysis, coliform group of bacteria may be differentiated by the presumptive test, the confirmed test 
and the complete test. The Presumptive test was done to confirm the presence of lactose-fermenting gas-producing bacteria. It was used to determine the Most Probable Number (MPN) of coliforms in a sample of water beside their properties of fermenting lactose and producing gas. The confirmed and the complete test are meant for differentiating the coliform with that of non-coliforms. All these tests were performed by following the standard methods outlined in APHA (1998).

\section{Water Quality Index (WQI)}

WQI is an abyssal number that combines the various water quality values into a single number by normalizing values to subjective rating curves. All these parameters or characteristics occur in variable ranges and expressed in various units. The WQI takes the complex scientific information into a single number. For this purpose, thirteen water quality parameters were selected. Values used for each parameter were the mean value of the three sites of four replicates of each site.

In the formulation of WQI, the 'standards' (permissible values of various parameters) for the drinking water used in this study were those recommended by the WHO (2004). The calculation and formulation of the WQI involved the following steps (Alobaidy et al. 2010).

\section{First step}

Each of the thirteen parameters has been assigned a weight (AWi) ranging from 1 to 4 depending on the collective expert opinions taken from different previous studies (Prati et al. 1971; Ramakrishnaiah et al. 2009 and Alobaidy et al. 2010). The mean values for the weights of each parameter have been shown in Table 1. However, a relative weight of 1 was considered as the least significant and 4 as the most significant.

\section{Second step}

The relative weight (RW) was calculated using the following equation:

$\mathrm{RW}=\frac{\mathrm{AWi}}{\sum_{i=1}^{n} \mathrm{AWi}}$

where, $\mathrm{RW}=$ the relative weight, $\mathrm{AW}=$ the assigned weight of each parameter, $n=$ the number of parameters. The calculated relative weight (RW) values of each parameter have been given in Table 2 .

\section{Third step}

A quality rating scale (Qi) for all the parameters except $\mathrm{pH}$ and DO was assigned by dividing its concentration in each water sample by its respective standard according to the drinking water guidelines recommended by the WHO, the result was then multiplied by 100 .

$\mathrm{Qi}=[\mathrm{Ci} / \mathrm{Si}] \times 100$

While, the quality rating for $\mathrm{pH}$ or $\mathrm{DO}\left(\mathrm{Q}_{\mathrm{pH}}, \mathrm{DO}\right)$ was calculated on the basis of,

$\mathrm{Q}_{\mathrm{pH}}, \mathrm{DO}=\left[\frac{\mathrm{Ci}-\mathrm{Vi}}{\mathrm{Si}-\mathrm{Vi}}\right] \times 100$

where, $\mathrm{Q} i=$ the quality rating, $\mathrm{Ci}=$ value of the water quality parameter obtained from the laboratory analysis, $\mathrm{Si}=$ value of the water quality parameter obtained from recommended $\mathrm{WHO}$, and $\mathrm{Vi}=$ the ideal value which is considered as 7.0 for $\mathrm{pH}$ and 14.6 for DO.

Equations (2) and (3) ensure that $\mathrm{Qi}=0$ when a pollutant is totally absent in the water sample and $\mathrm{Qi}=100$ when the value of this parameter is just equal to its permissible value. Thus, the higher the value of Qi is, the more polluted is the water (Mohanty 2004).

\section{Fourth step}

Finally, for computing the WQI, the sub indices (SI i) were first calculated for each parameter, and then used to compute the WQI as in the following equations:

$\mathrm{SI} \mathrm{i}=\mathrm{RW} \times \mathrm{Qi}$

$\mathrm{WQI}=\sum_{i=1}^{n} \mathrm{SI} \mathrm{i}$

The computed WQI values could be classified as $<50=$ Excellent; $\quad 50-100=$ Good; $\quad 100-200=$ Poor; 200-300 = Very poor; $>300=$ Unsuitable (Prati et al. 1971; Ramakrishnaiah et al. 2009 and Alobaidy et al. 2010).

\section{Results and discussion}

Data of all the sixteen physico-chemical parameters obtained under two sampling operations during a period of two years (2014-2015) from the sacred Lake Satopanth of Garhwal Himalaya have been presented in Table 3. A very little variation $\left(0.1\right.$ to $\left.0.3{ }^{\circ} \mathrm{C}\right)$ in the mean value of water temperature of Satopanth Lake was observed during the study period. However, the temperature of the surface water was about 13 to $14{ }^{\circ} \mathrm{C}$ recorded from Ximencuo, a typical glacial lake on the eastern Qinghai-Tibetan plateau 
Table 1 Assigned weight values adopted from the literature (Prati et al.1971; Ramakrishnaiah et al. 2009 and Alobaidy et al. 2010)

\begin{tabular}{|c|c|c|c|c|}
\hline \multirow[t]{2}{*}{ Parameters } & \multicolumn{3}{|c|}{ Sampling sites } & \multirow[t]{2}{*}{ Mean value } \\
\hline & $\mathrm{S}_{1}$ & $\mathrm{~S}_{2}$ & $\mathrm{~S}_{3}$ & \\
\hline $\mathrm{pH}$ & 3 & 3 & 3 & 3.0 \\
\hline DO (mg/L) & 4 & 4 & 4 & 4.0 \\
\hline Conductivity $(\mu \mathrm{S} / \mathrm{cm})$ & 3 & 2 & 3 & 2.7 \\
\hline TDS (mg/L) & 2 & 2 & 3 & 2.3 \\
\hline Free $\mathrm{CO}_{2}(\mathrm{mg} / \mathrm{L})$ & 1 & 1 & 1 & 1.0 \\
\hline Total hardness (mg/L) & 3 & 3 & 3 & 3.0 \\
\hline Calcium (mg/L) & 3 & 2 & 3 & 2.7 \\
\hline Magnesium (mg/L) & 2 & 3 & 2 & 2.3 \\
\hline Chlorides (mg/L) & 4 & 4 & 4 & 4.0 \\
\hline Total alkalinity (mg/L) & 4 & 3 & 4 & 3.7 \\
\hline Nitrates (mg/L) & 1 & 2 & 1 & 1.3 \\
\hline Sulphates (mg/L) & 1 & 1 & 1 & 1.0 \\
\hline Total coliform & 4 & 4 & 4 & 4.0 \\
\hline
\end{tabular}

Table 2 Relative weight of the water quality parameters

\begin{tabular}{lllll}
\hline Parameters & Water quality standard (WHO) & Water quality standard (BIS) & Assigned weight (AW) & Relative weight (RW) \\
\hline $\mathrm{pH}(\mathrm{pH}$ unit) & $6.5-8.5(8.0)$ & $6.5-8.5$ & 3.0 & 0.085714 \\
$\mathrm{DO}(\mathrm{mg} / \mathrm{L})$ & 5.0 & 6.0 & 4.0 & 0.114286 \\
Conductivity $(\mu \mathrm{S} / \mathrm{cm})$ & 250 & 300 & 2.7 & 0.077143 \\
TDS $(\mathrm{mg} / \mathrm{L})$ & 500 & 500 & 2.3 & 0.065714 \\
Free $\mathrm{CO}_{2}(\mathrm{mg} / \mathrm{L})$ & 250 & - & 1.0 & 0.028571 \\
Total hardness $(\mathrm{mg} / \mathrm{L})$ & 200 & 200 & 3.0 & 0.085714 \\
Calcium $(\mathrm{mg} / \mathrm{L})$ & 75 & 75 & 2.7 & 0.077143 \\
Magnesium $(\mathrm{mg} / \mathrm{L})$ & 30 & 30 & 2.3 & 0.065714 \\
Chlorides $(\mathrm{mg} / \mathrm{L})$ & 250 & 250 & 4.0 & 0.114286 \\
Total alkalinity $(\mathrm{mg} / \mathrm{L})$ & 200 & 200 & 3.7 & 0.105714 \\
Nitrates $(\mathrm{mg} / \mathrm{L})$ & 45 & 45 & 1.3 & 0.037143 \\
Sulphates $(\mathrm{mg} / \mathrm{L})$ & 200 & 200 & 4.0 & 0.028571 \\
Total coliform $(100 \mathrm{~mL})$ & 10 & 00 & 35.0 & 0.114286 \\
Total & & & & 1.0 \\
\hline
\end{tabular}

(QTP) (Pu et al. 2013). This difference in the water temperature of these glacial lakes may be due to the difference in the physiography and location of these two glacial lakes. The glacial Lake Ximencuo is also fed by modern glacier via shallow small streams ( $\mathrm{Pu}$ et al. 2013). The $\mathrm{pH}$ of Satopanth Lake water varied from 6.85 to 7.10 , indicating that the water is almost neutral in nature. Similar result was recorded by Mihaiescu et al. (2013) on glacial lakes in the Romanian Carpathians. However, the $\mathrm{pH}$ value of glacial Lake Ximencuo water was about 8.9, which is alkaline in nature (Pu et al. 2013). $\mathrm{pH}$ is a key factor that decide the suitability of water for various purposes. The observed values of Satopanth Lake show a relative agreement with $\mathrm{pH}$ values of surface water, which lie within the range of 6.5-8.5 given as per WHO standards of drinking water.

The mean values of dissolved oxygen (DO) varied from 5.90 to $6.00 \mathrm{mg} / \mathrm{L}$ which never reached the critical values $5.0 \mathrm{mg} / \mathrm{L}$ given in WHO standards for drinking water. Similar results were recorded by Saini et al. (2008) for three Himalayan lakes and Mihaiescu et al. (2012) for Balea and Caltun lakes. The reason behind the low concentration of dissolved oxygen in the lake water is the location of the Satopanth Lake in the higher Himalaya. As we move toward the higher altitude, the concentration of 
Table 3 Statistical summary of the Satopanth Lake water quality data

\begin{tabular}{|c|c|c|c|c|c|c|}
\hline \multirow[t]{2}{*}{ Physico-chemical Parameters } & \multicolumn{3}{|l|}{2014} & \multicolumn{3}{|l|}{2015} \\
\hline & $\mathrm{S} 1(\overline{\mathrm{X}} \pm \mathrm{SD})$ & $\mathrm{S} 2(\overline{\mathrm{X}} \pm \mathrm{SD})$ & $\mathrm{S} 3(\overline{\mathrm{X}} \pm \mathrm{SD})$ & $\mathrm{S} 1(\overline{\mathrm{X}} \pm \mathrm{SD})$ & $\mathrm{S} 2(\overline{\mathrm{X}} \pm \mathrm{SD})$ & $\mathrm{S} 3(\overline{\mathrm{X}} \pm \mathrm{SD})$ \\
\hline Air temperature $\left({ }^{\circ} \mathrm{C}\right)$ & $1.00 \pm 0.28$ & $1.00 \pm 0.28$ & $0.95 \pm 0.35$ & $1.10 \pm 0.42$ & $0.95 \pm 0.35$ & $1.00 \pm 0.28$ \\
\hline Water temperature $\left({ }^{\circ} \mathrm{C}\right)$ & $0.15 \pm 0.07$ & $0.20 \pm 0.14$ & $0.15 \pm 0.07$ & $0.20 \pm 0.14$ & $0.20 \pm 0.00$ & $0.15 \pm 0.07$ \\
\hline $\mathrm{pH}$ & $6.85 \pm 0.07$ & $6.85 \pm 0.07$ & $6.90 \pm 0.00$ & $6.85 \pm 0.07$ & $7.10 \pm 0.00$ & $6.95 \pm 0.21$ \\
\hline $\mathrm{DO}(\mathrm{mg} / \mathrm{L})$ & $5.90 \pm 0.14$ & $6.00 \pm 0.00$ & $5.80 \pm 0.00$ & $5.80 \pm 0.00$ & $5.90 \pm 0.14$ & $6.00 \pm 0.00$ \\
\hline Conductivity $(\mu \mathrm{S} / \mathrm{cm})$ & $163.00 \pm 2.83$ & $164.00 \pm 1.41$ & $162.00 \pm 0.00$ & $166.50 \pm 4.95$ & $165.50 \pm 3.54$ & $167.50 \pm 3.54$ \\
\hline Salinity $\left({ }^{\mathrm{SAL}}\right)$ & $0.10 \pm 0.00$ & $0.10 \pm 0.00$ & $0.10 \pm 0.00$ & $0.10 \pm 0.00$ & $0.10 \pm 0.00$ & $0.10 \pm 0.00$ \\
\hline TDS (mg/L) & $88.00 \pm 1.41$ & $88.00 \pm 1.41$ & $89.00 \pm 2.83$ & $89.50 \pm 2.12$ & $88.50 \pm 3.54$ & $88.00 \pm 2.83$ \\
\hline Free $\mathrm{CO}_{2}(\mathrm{mg} / \mathrm{L})$ & $8.40 \pm 0.14$ & $8.40 \pm 0.00$ & $8.40 \pm 0.00$ & $8.60 \pm 0.28$ & $8.50 \pm 0.14$ & $8.60 \pm 0.28$ \\
\hline Total Hardness (mg/L) & $22.00 \pm 1.41$ & $22.00 \pm 1.41$ & $22.00 \pm 1.41$ & $22.00 \pm 0.00$ & $22.50 \pm 2.12$ & $22.50 \pm 2.12$ \\
\hline Calcium (mg/L) & $7.89 \pm 0.00$ & $7.90 \pm 0.01$ & $7.89 \pm 0.00$ & $7.95 \pm 0.08$ & $7.95 \pm 0.08$ & $7.88 \pm 0.01$ \\
\hline Magnesium (mg/L) & $0.565 \pm 0.35$ & $0.56 \pm 0.34$ & $0.56 \pm 0.35$ & $0.53 \pm 0.05$ & $0.65 \pm 0.47$ & $0.66 \pm 0.46$ \\
\hline Chlorides (mg/L) & $9.90 \pm 0.06$ & $9.90 \pm 0.06$ & $9.63 \pm 0.16$ & $9.83 \pm 0.16$ & $9.14 \pm 0.88$ & $9.64 \pm 0.17$ \\
\hline Total Alkalinity (mg/L) & $181.50 \pm 2.12$ & $180.00 \pm 1.41$ & $180.00 \pm 1.41$ & $179.00 \pm 0.00$ & $179.00 \pm 2.83$ & $179.00 \pm 2.83$ \\
\hline Nitrates (mg/L) & $0.13 \pm 0.00$ & $0.13 \pm 0.00$ & $0.13 \pm 0.00$ & $0.13 \pm 0.00$ & $0.13 \pm 0.00$ & $0.13 \pm 0.01$ \\
\hline Sulphates (mg/L) & $0.73 \pm 0.01$ & $0.73 \pm 0.01$ & $0.73 \pm 0.00$ & $0.73 \pm 0.01$ & $0.73 \pm 0.01$ & $0.73 \pm 0.00$ \\
\hline Phosphates (mg/L) & $0.062 \pm 0.38$ & $0.060 \pm 0.00$ & $0.060 \pm 0.00$ & $0.060 \pm 0.00$ & $0.060 \pm 0.00$ & $0.62 \pm 0.01$ \\
\hline
\end{tabular}

oxygen in the atmosphere goes down. So, less amount of atmospheric oxygen gets dissolved in the water of the lake. In any aquatic ecosystem, dissolved oxygen is an important parameter for the survival of most forms of aquatic life, besides being the most reliable criterion for assessing the trophic status and the magnitude of eutrophication (Edmondson 1966).

The electrical conductivity (EC) greatly affects the taste of water. It is an indirect measure of total dissolved salts available in the water. Electrical conductivity ranged from 162 to $167.5 \mu \mathrm{S} / \mathrm{cm}$ in the water of Satopanth Lake. However, a high electrical conductivity $(530 \mu \mathrm{S} / \mathrm{cm})$ was recorded in the surface water of glacial lake Ximencuo $(\mathrm{Pu}$ et al. 2013). Low electrical conductivity is a characteristic of good quality of water. Electrical conductivity depends upon the quantity of dissolved salts present in water. The mean value is below the range of $250 \mu \mathrm{S} / \mathrm{cm}^{-1}$ as per WHO standards. Similar results were recorded by ChaconTorres and Rosas-Monge (1998) for high altitude Mexican lake; Saini et al. (2008) for three Himalayan lakes; Mihaiescu et al. (2012) for Balea and Caltun lakes and Singh et al. (2014) for high altitude lakes of Lahaul-Spiti in Himachal Pradesh.

Salinity of the samples was recorded $0.1^{\mathrm{SAL}}$ throughout the sampling period. This represents that a very low quantity of salts is dissolved in the water of the lake. Salinity is the dissolved salt content of a water body. It is an important factor in determining many aspects of the chemistry of natural water and of biological processes within it.

The mean value of total dissolved solids (TDS) ranged between 88.0 and $89.5 \mathrm{mg} / \mathrm{L}$ in the water of Satopanth Lake, which is much lower than $500 \mathrm{mg} / \mathrm{L}$ as per WHO standards. Low concentration $\left(44.0 \mathrm{mg} / \mathrm{L}^{-1}\right)$ of total dissolved solids (TDS) was also recorded in the glacial Lake Ximencuo ( $\mathrm{Pu}$ et al. 2013). Electrical conductivity and TDS are closely related to each other. Electrical conductivity and TDS concentration are directly proportional to each other.

The mean values of free $\mathrm{CO}_{2}$ varied between 8.40 and $8.60 \mathrm{mg} / \mathrm{L}$, which is very less than the prescribed limit of $250 \mathrm{mg} / \mathrm{L}$ given by WHO for drinking water. The high value of free $\mathrm{CO}_{2}$ content is an indication of high degree of pollution (Coole 1979).

The total hardness is also an important parameter of water quality for using in domestic, industrial and agricultural purposes. Hardness of water is due to major cations present in the water body. The mean value of total hardness varied from 22.0 to $22.5 \mathrm{mg} / \mathrm{L}$ against the WHO standard which is $200 \mathrm{mg} / \mathrm{L}$ for drinking water. The main reason for less amount of total hardness is that the fewer amounts of cations are dissolved in water. At such, a high altitude, water body rarely contains more cations, as there is no collision of water with the rocks and other minerals.

The mean value for calcium varied from 7.88 to $7.95 \mathrm{mg} / \mathrm{L}$ against $75 \mathrm{mg} / \mathrm{L}$ of WHO standard given for drinking water. Magnesium varied from 0.53 to $0.66 \mathrm{mg} / \mathrm{L}$, 


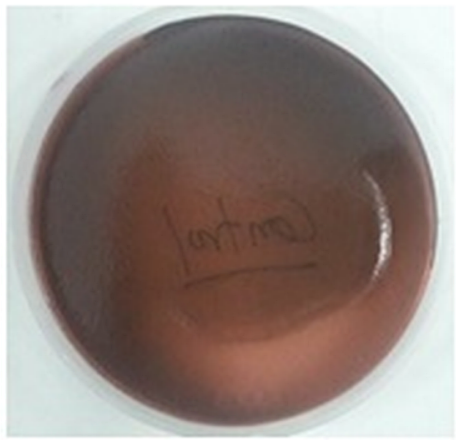

Control

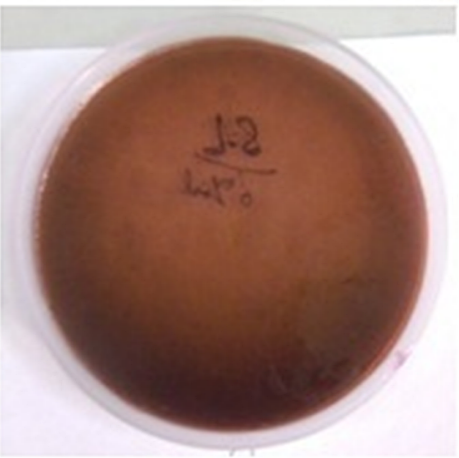

$1.0 \mathrm{ml}$

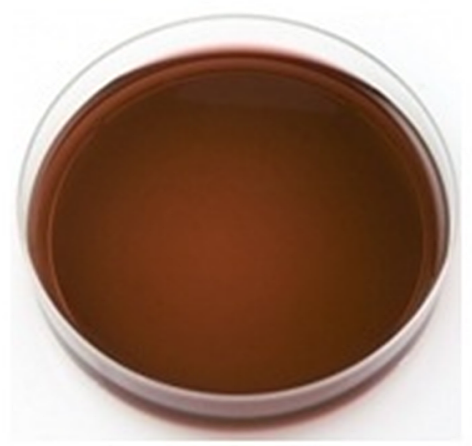

$0.1 \mathrm{ml}$

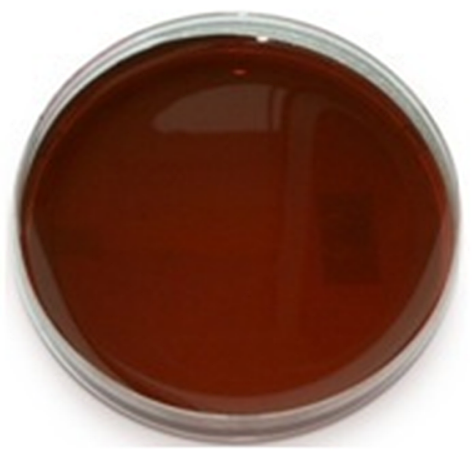

$10 \mathrm{ml}$

Fig. 2 Culture plates for coliform test

which is less than the WHO standard $(30 \mathrm{mg} / \mathrm{L})$ for drinking water. Similar results were observed by ChaconTorres and Rosas-Monge (1998) for high altitude Mexican lake; Saini et al. (2008) for three Himalayan lakes; Mihaiescu et al. (2012) for Balea and Caltun lakes and Mihaiescu et al. (2013) for glacial lakes in the Romanian Carpathians. Mean values of chlorides varied from 9.14 to $9.90 \mathrm{mg} / \mathrm{L}$. The permissible limit by WHO is $250 \mathrm{mg} / \mathrm{L}$, which is very high than the concentration observed in the water of Satopanth Lake.

The alkalinity of water is usually caused by the presence of carbonates, bicarbonates and hydroxyl ions, and less frequently by borates, silicates and phosphates. Alkalinity is not a pollutant. It is a total measure of the substances in water that have "acid-neutralizing" ability. Alkalinity of the water of the Satopanth Lake ranged from 179.0 to $181.5 \mathrm{mg} / \mathrm{L}$ during the study period. The observed values of alkalinity were less than the permissible level $(200 \mathrm{mg} /$ $\mathrm{L}^{-1}$ ) recommended by the WHO for drinking water.

Nitrates were the most abundant form of nitrogen compound. The mean value of nitrates present in the lake water was $0.13 \mathrm{mg} / \mathrm{L}$. This is very less than the WHO permissible concentration of $45 \mathrm{mg} / \mathrm{L}$ for drinking water. Sulphates were also found in small amount $(0.73 \mathrm{mg} / \mathrm{L})$. Permissible limit of sulphates for drinking water prescribed by WHO is $200 \mathrm{mg} / \mathrm{L}$. Phosphorous is generally 
recognized as one of the key nutrients in the productivity of fresh water, as it is an essential element for determining the fertility of lakes. The mean value of phosphates in the water of Satopanth Lake was around $0.06 \mathrm{mg} / \mathrm{L}$. Almost similar results of water quality were observed by ChaconTorres and Rosas-Monge (1998) for high altitude Mexican lake; Saini et al. (2008) for three Himalayan lakes and Mihaiescu et al. (2012) for Balea and Caltun lakes.

\section{Water Quality Index (WQI) analysis}

The Water Quality Index (WQI) was used to accumulate diverse parameters and their dimensions in a single value, that displaying the water quality of Satopanth Lake. It was observed from the computed data for all the thirteen water quality parameters that the value of WQI was 28.504. Therefore, the water of Satopanth Lake can be categorized as "Excellent" during the sampling period. Detailed statistics for all the water quality examined during the assessment are shown in Table 3. To reach a better view on the water quality of Satopanth Lake, selected results from the physico-chemical parameters are presented in Table 3.

In the coliform test, no coliform bacterial colony was shown on the Eosin Methylene Blue (EMB) agar plate (Fig. 2). All the tubes of lactose broth used in the presumptive test to ensure the presence of coliform bacteria showed negative results. $\mathrm{No} \mathrm{CO}_{2}$ formation was recorded in the inverted Durham tubes and no change was seen in the lactose broth media.

\section{Conclusion}

The results obtained on all the physico-chemical parameters of surface water of the glacier-fed Lake Satopanth in Garhwal Himalaya revealed that the water quality of the lake is "excellent" following the standards of WHO and Bureau of Indian Standards (BIS). The value (28.504) of Water Quality Index (WQI) computed after accumulating diverse physico-chemical parameters of lake water also confirms the above assessment of the water quality. The coliform test also supports these findings of "excellent" water quality of the water of Satopanth Lake. This maiden study on the assessment of water quality of the sacred glacier-fed Lake Satopanth of the remote area of the Himalaya can be a good reference for further study on Himalayan glacial lakes.

Acknowledgements One of the authors (Rahul Kumar) thankfully acknowledge the fellowship given by the University Grant Commission, New Delhi through Hemvati Nandan Bahuguna Garhwal University (A Central University), Srinagar-Garhwal, Uttarakhand, India, for undertaking the present work.
Open Access This article is distributed under the terms of the Creative Commons Attribution 4.0 International License (http:// creativecommons.org/licenses/by/4.0/), which permits unrestricted use, distribution, and reproduction in any medium, provided you give appropriate credit to the original author(s) and the source, provide a link to the Creative Commons license, and indicate if changes were made.

\section{References}

Ageta Y, Iwata S, Yabuki H, Naito N, Sakai A, Narama C, Karma T (2000) Expansion of glacier lakes in recent decades in the Bhutan Himalayas. Debris-Covered Glaciers Proceedings of a Workshop held at Seattle, Washington, USA. IAHS Publication 264:165-175

Alobaidy AHM, Abid HS, Maulood BK (2010) Application of water quality index for assessment of Dokan Lake ecosystem, Kurdistan region, Iraq. J Water Resour Prot 2:792-798

APHA (1998) Standard methods for the estimation of water and waste water, 20th edn. American Waste Water Association and Water Pollution Control Federation, Washington

Bhambri R, Mehta M, Dobhal DP, Gupta AK (2015) Glacier Lake Inventory of Uttarakhand. Wadia Institute Of Himalayan Geology, Dehradun, pp 1-89

Chacon-Torres A, Rosas-Monge C (1998) Water quality characteristics of a high altitude oligotrophic Mexican Lake. Aquat Ecosyst Health Manage 1:237-243

Che T, Xiao L, Liou YA (2014) Changes in glaciers and glacial lakes and the identification of dangerous glacial lakes in the Pumqu river basin, Xizang (Tibet). Adv Meteorol 2014:1-8

Coole GR (1979) A Text book of Limnology. The Mosley Co London, New York, p 410

Edmondson WT (1966) Changes in the oxygen deficit of Lake Washington. Verhandlungen des Internationalen Verein Limnologie 16:153-158

Fairbridge RW (1968) Glacier Lakes. In: Fairbridge RW (ed) The Encyclopedia of Geomorphology. Reinhold, New York, pp 444-453

Fujita K, Nishimura K, Komori J, Iwata S, Ukita J, Tadono T, Koike $T$ (2012) Outline of research project on glacial lake outburst floods in the Bhutan Himalayas: global. Environ Res 16:3-12

Mihaiescu T, Pop AI, Mihaiescu R, Muntean E, Tanaselia C, Maloş C, Oprea MG, Ozunu A (2012) Study on Balea and Calţun Glaciar Lakes, from Fagaraş Mountains. ProEnvironment 5:260-265

Mihaiescu R, Pop AI, Mihaiescu T, Oprea MG, Tanaselia C, Ozunu A (2013) Physico-chemical properties of some glacial lakes: in The Romanian Carpathians. Carpathian J Earth Environ Sci 8(4):5-11

Mohanty SK (2004) Water Quality Index of four religious ponds and its seasonal variations in the temple City, Bhuvaneshwar. In: Kumar A (ed) Water pollution. APH Publishing Corporation, New Delhi, pp 211-218

Prati L, Paranello R, Pesarin P (1971) Assessment of surface water quality by single index of pollution. Water Res 5:741-751

$\mathrm{Pu}$ Y, Nace T, Meyers PA, Zhang H, Wang Y, Cl Zhang, Shao X (2013) Paleoclimate changes of the last $1000 \mathrm{yr}$ on the eastern Qinghai-Tibetan Plateau recorded by elemental, isotopic and molecular organic matter proxies in sediment from glacial Lake Ximencuo. Palaeogeogr Palaeoclimatol Palaeoecol 379(380):39-53 
Raj KBG, Remya SN, Kumar VK (2013) Remote sensing-based hazard assessment of glacial lakes in Sikkim Himalaya. Curr Sci 104(3):359-364

Ramakrishnaiah CR, Sadashivaiah C, Ranganna G (2009) Assessment of water quality index for the ground water in Tumkur Taluk. E J Chem 6(2):523-530

Saini RK, Swain S, Patra A, Khanday GJ, Gupta H, Purushothaman P, Chakrapani GJ (2008) Water chemistry of three Himalayan Lakes: Dal (Jammu \& Kashmir), Khajjiar (Himachal Pradesh) and Nainital (Uttarakhand). Himalayan Geol 29(1):63-72

Singh Y, Khattar JIS, Singh DP, Rahi P, Gulati A (2014) Limnology and cyanobacterial diversity of high altitude lakes of LahaulSpiti in Himachal Pradesh. Indian J Biosci 39(4):643-657

UNCSD (2012) Report of the United Nations Conference on Sustainable Development, Rio de Janeiro, Brazil 20-22 June 2012, United Nations, New York, pp 41-42

Westoby MJ, Glasser NF, Brasington J, Hambrey MJ, Quincey DJ, Reynolds JM (2014) Research Summary: challenges associated with modelling outburst floods from moraine dammed glacial lakes. Earth Sci Rev 134:137-159

Wetzel RG, Likens GE (1991) Limnological Analysis, 2nd edn. Springer-Verlag, New York, pp 1-391

World Health Organization (WHO) (2004) Guidelines for drinkingwater quality, 3rd edn. World Health Organization (WHO), Geneva

WWF (2005) An Overview of Glacial Retreat, and Subsequent Impacts in Nepal, India and China. World Wide Fund for Nature, Nepal, pp 1-79

\section{Publisher's Note}

Springer Nature remains neutral with regard to jurisdictional claims in published maps and institutional affiliations. 